Article

\title{
Depolymerization and hydrodeoxygenation of lignin to aromatic hydrocarbons with a Ru catalyst on a variety of $\mathrm{Nb}$-based supports
}

\author{
Di Ma†, Shenglu Lu†, Xiaohui Liu *, Yong Guo, Yanqin Wang \# \\ Shanghai Key Laboratory of Functional Materials Chemistry, Research Institute of Industrial Catalysis, School of Chemistry and Molecular Engineering, \\ East China University of Science and Technology, Shanghai 200237, China
}

\section{A R T I C L E I N F O}

\section{Article history:}

Received 20 December 2018

Accepted 25 January 2019

Published 5 April 2019

\section{Keywords:}

Lignin

Aromatic hydrocarbons

Nb-based supports

Lewis acid sites

$\mathrm{Ru}$

\begin{abstract}
A B S T R A C T
Efficient conversion of lignin to aromatic hydrocarbons via depolymerization and subsequent hydrodeoxygenation is important. Previously, we found that $\mathrm{NbO}_{x}$ species played a key role in the activation and cleavage of $\mathrm{C}-\mathrm{O}$ bonds in lignin and its model compounds. In this study, commercial niobic acid (HY-340), niobium phosphate (NbPO-CBMM) and lab-made layered niobium oxide $\left(\mathrm{Nb}_{2} \mathrm{O}_{5}\right.$-Layer) were chosen as supports to study the effect of Brönsted and Lewis acids on the activation of $\mathrm{C}-\mathrm{O}$ bonds in lignin conversion. A variety of Ru-loaded, Nb-based catalysts with different $\mathrm{Ru}$ particle sizes were prepared and applied to the conversion of $p$-cresol. The results show that all the $\mathrm{Ru} / \mathrm{Nb}$-based catalysts produce high mole yields of $\mathrm{C}_{7}-\mathrm{C}_{9}$ hydrocarbons (82.3\%-99.1\%). What's more, $\mathrm{Ru} / \mathrm{Nb}_{2} \mathrm{O}_{5}$-Layer affords the best mole yield of $\mathrm{C}_{7}-\mathrm{C}_{9}$ hydrocarbons and selectivity for $\mathrm{C}_{7}-\mathrm{C}_{9}$ aromatic hydrocarbons, of up to $99.1 \%$ and $88.0 \%$, respectively. Moreover, it was found that Lewis acid sites play important roles in the depolymerization of enzymatic lignin into phenolic monomers and the cleavage of the $\mathrm{C}-\mathrm{O}$ bond of phenols. Additionally, the electronic state and particle size of $\mathrm{Ru}$ are significant factors which influence the selectivity for aromatic hydrocarbons. A partial positive charge on the metallic Ru surface and a smaller Ru particle size are beneficial in improving the selectivity for aromatic hydrocarbons.
\end{abstract}

(C) 2019, Dalian Institute of Chemical Physics, Chinese Academy of Sciences. Published by Elsevier B.V. All rights reserved.

\section{Introduction}

Lignocellulosic biomass consists of lignin, cellulose, and hemicellulose. Effective utilization of lignocellulosic biomass is ineluctable and necessary, due to the accelerating consumption and dwindling reserves of petroleum-based chemicals [1-6]. It is well known that aromatic hydrocarbons are ideal additives for aviation fuel, due to their high energy density and other properties [7]. Lignin is rich in aromatic rings and is the only renewable energy source for aromatic compounds [8,9]. Thus, converting lignins into aromatic hydrocarbon compounds is one of the most promising processes in biomass utilization, which usually include lignin depolymerization and subsequent hydrodeoxygenation steps [10-14].

Recently, $\mathrm{NbO}_{x}$ species have been found to play a key role in the activation and cleavage of $\mathrm{C}_{\text {aliphatic }}-\mathrm{O}$ and $\mathrm{C}_{\text {aromatic }}-\mathrm{O}$ bonds in both lignin and its model compounds [15-18]. For example, $p$-cresol, a typical lignin model compound, can be efficiently

\footnotetext{
* Corresponding author. E-mail: xhliu@ecust.edu.cn

\# Corresponding author. E-mail: wangyanqin@ecust.edu.cn

† These authors contribute equally.

The work was supported by the National Natural Science Foundation of China (21832002, 21872050, 21808063) and the Natural Science Foundation of Shanghai (18ZR1408500).

DOI: S1872-2067(19)63317-6 | http://www.sciencedirect.com/science/journal/18722067 | Chin. J. Catal., Vol. 40, No. 4, April 2019
} 
converted into toluene over $\mathrm{Ru} / \mathrm{Nb}_{2} \mathrm{O}_{5}-\mathrm{SiO}_{2}$ catalysts using 2-PrOH as the hydrogen source [17]. Reaction pathway studies show that toluene was produced via the direct deoxygenation (DDO) route ( $\mathrm{C}-\mathrm{O}$ cleavage without saturation of the aromatic ring). Furthermore, niobium-based catalysts have shown great promise in converting lignin into arenes, despite the robust and complex lignin structure. Shao et al. [18] reported the direct conversion of lignin over $\mathrm{Ru} / \mathrm{Nb}_{2} \mathrm{O}_{5}$ catalytic systems in water, with a high yield of liquid hydrocarbons (a mass yield of 35.5 $w t \%)$ and an exceptionally high arene selectivity for $\mathrm{C}_{7}-\mathrm{C}_{9}$ hydrocarbons (71 wt $\%$ ). The $\mathrm{Ru} / \mathrm{Nb}_{2} \mathrm{O}_{5}$ catalyst in this process not only depolymerized the raw lignin to phenolic monomers via the effective cleavage of $\mathrm{C}_{\text {aliphatic }}-\mathrm{O}-\mathrm{C}$ bonds in the lignin network, but also promoted the hydrodeoxygenation of phenolics to arenes.

In this study, we compared the structures and properties of different commercial niobium-based catalysts and our lab-made layered $\mathrm{Nb}_{2} \mathrm{O}_{5}$ ( $\mathrm{Nb}_{2} \mathrm{O}_{5}$-Layer), and subsequently studied the catalytic performance for both lignin and $p$-cresol conversion to arenes over these Nb-based carrier supported Ru catalysts. As Companhia Brasileira de Metalurgia e Mineração (CBMM) is the world's leading niobium manufacturer, we chose HY-340 and niobium phosphate produced by CBMM as supports and compared them with lab-made layered $\mathrm{Nb}_{2} \mathrm{O}_{5}$. It was found that the $\mathrm{Ru} / \mathrm{Nb}_{2} \mathrm{O}_{5}$-Layer catalyst had the best performance and durability. Moreover, the relationship between the catalytic performance in the depolymerization and hydrodeoxygenation of lignin to aromatic hydrocarbons and the structural properties of the $\mathrm{Ru}$ catalysts supported on Nb-based materials was clarified by powder X-ray diffraction (XRD), Brunauer-Emmett-Teller (BET) analysis, thermogravimetry (TG), pyridine-absorbed Fourier transform infrared spectroscopy (Py-FTIR), CO-chemisorption, and X-ray photoelectron spectroscopy (XPS).

\section{Experimental}

\subsection{Materials}

$\mathrm{RuCl}_{3} \cdot 3 \mathrm{H}_{2} \mathrm{O}$ was purchased from Heraeus Materials Technology Shanghai Co. Ltd. $p$-cresol was purchased from J \& K Co. Ltd. HY-340 and niobium phosphate (NbPO) were obtained from CBMM. Enzymatic lignin was purchased from Shandong Longlive Bio-Technology Co., Ltd. This lignin is obtained by the enzyme-catalyzed hydrolysis of cellulose from corncobs. The distribution and quantities of the lignin monomers are shown in Table S1. Layered $\mathrm{Nb}_{2} \mathrm{O}_{5}\left(\mathrm{Nb}_{2} \mathrm{O}_{5}\right.$-Layer) was synthesized using a hydrothermal method following the literature procedure [19]. Specifically, we used lab-synthesized niobium oxalate as the niobium precursor.

\subsection{Catalyst preparation}

The catalysts $\left(\mathrm{Ru} / \mathrm{Nb}_{2} \mathrm{O}_{5}\right.$-Layer, $\mathrm{Ru} / \mathrm{HY}-340$, and $\mathrm{Ru} / \mathrm{NbPO}-\mathrm{CBMM}$ ) were prepared by the incipient wetness impregnation method, using $\mathrm{RuCl}_{3} \cdot 3 \mathrm{H}_{2} \mathrm{O}$ as the precursor. After impregnation, the resulting catalysts were dried at $50{ }^{\circ} \mathrm{C}$ for 12 h, reduced at $400{ }^{\circ} \mathrm{C}$ for $4 \mathrm{~h}$ under 10 vol\% $\mathrm{H}_{2} / \mathrm{Ar}$ flow, and then purged with $\mathrm{N}_{2}$ for $2 \mathrm{~h}$ until they reached ambient temperature.

Additionally, Ru-loaded Nb-based catalysts with specific $\mathrm{Ru}$ particle sizes were prepared by adsorption of colloidal Ru nanoparticles (NPs) onto the $\mathrm{Nb}_{2} \mathrm{O}_{5}$-Layer, HY-340, and NbPO-CBMM supports, which were designated $\mathrm{Ru} @ \mathrm{Nb}_{2} \mathrm{O}_{5}$-Layer, Ru@HY-340, and Ru@NbPO-CBMM, respectively [20]. Colloidal Ru NPs with mean sizes of 1.2 and $1.8 \mathrm{~nm}$ were first prepared by the reduction of $\mathrm{RuCl}_{3}$ with ascorbic acid, in the aqueous phase, at $80{ }^{\circ} \mathrm{C}$, for 1 and $5 \mathrm{~min}$, respectively. Then, the support was added to the colloidal Ru particle solution and the mixture was stirred for $24 \mathrm{~h}$. Finally, the solid product was collected by filtration, washed with deionized water, dried at $50{ }^{\circ} \mathrm{C}$ in a vacuum oven, and solidified at $300{ }^{\circ} \mathrm{C}$ for 4 h under a $\mathrm{N}_{2}$ flow. The initial content of Ru NPs was 2.0 wt $\%$.

\subsection{Characterization}

The powder XRD patterns were recorded with a Rigaku D/max-2550VB/PC diffractometer, using $\mathrm{Cu} K_{\alpha}(\lambda=0.15406$ $\mathrm{nm}$ ) radiation, operating at $40 \mathrm{kV}$ and $40 \mathrm{~mA}$.

The quantities of metals in the catalysts were determined using inductively coupled plasma atomic emission spectroscopy (ICP-AES) on a Perkin-Elmer Optima 2100 DV spectrometer. Samples were digested in a mixture of $\mathrm{HF}$ and $\mathrm{H}_{2} \mathrm{SO}_{4}$.

X-ray photoelectron spectroscopy (XPS) was performed using a Thermo Scientific ESCA LAB-250 spectrometer with monochromatic $\mathrm{Al} \mathrm{K} \alpha$ radiation.

Nitrogen adsorption-desorption isotherms of the catalysts were measured at $-196{ }^{\circ} \mathrm{C}$ on a Micromeritics ASAP $2020 \mathrm{M}$ sorption analyzer. Prior to $\mathrm{N}_{2}$ adsorption, the catalysts were pre-treated under vacuum at $200{ }^{\circ} \mathrm{C}$ for $6 \mathrm{~h}$ to remove moisture and volatile impurities. The surface area was calculated using a multipoint Brunauer-Emmett-Teller (BET) method.

Thermogravimetry-differential thermal analysis (TG-DTA) of the catalyst was performed on PerkinElmer Pyris Diamond differential scanning calorimeter, under air, with a heating rate of $10{ }^{\circ} \mathrm{C} / \mathrm{min}$.

Infrared (IR) spectra of the pyridine adsorption were recorded on a Nicolet iS50 spectrometer, with 32 scans at an effective resolution of $4 \mathrm{~cm}^{-1} .20 \mathrm{mg}$ of sample was pressed into a self-supporting wafer. The disc was mounted in a quartz IR cell equipped with a $\mathrm{CaF}_{2}$ window and a vacuum system. Prior to adsorption, the samples were pretreated at $400{ }^{\circ} \mathrm{C}$ under vacuum, then cooled to $30^{\circ} \mathrm{C}$, and pyridine vapor was introduced into the cell. The samples were heated under vacuum at $100^{\circ} \mathrm{C}$ and spectra were recorded at room temperature. The quantification of acid sites was performed using the expressions reported by Emeis [21]:

$$
\begin{aligned}
& C_{\mathrm{L}}=\mathrm{K}_{\mathrm{L}} A_{1450}=\frac{\pi}{\operatorname{IMEC}_{\mathrm{L}}}\left(\frac{\mathrm{r}^{2}}{\mathrm{w}}\right) A_{1450} \\
& C_{\mathrm{B}}=\mathrm{K}_{\mathrm{B}} A_{1540}=\frac{\pi}{\operatorname{IMEC}_{\mathrm{B}}}\left(\frac{\mathrm{r}^{2}}{\mathrm{w}}\right) A_{1540}
\end{aligned}
$$

$C_{\mathrm{L}}$ and $C_{\mathrm{B}}$ are the concentrations of Lewis and Brönsted acid sites; $A_{1450}$ and $A_{1540}$ are the integrated areas of the bands at 
1450 and $1540 \mathrm{~cm}^{-1}$ in the original FTIR data, as shown in the Results and discussion section. $\mathrm{K}_{\mathrm{L}}$ and $\mathrm{K}_{\mathrm{B}}$ are the molar extinction constants for the Lewis and Brönsted acid sites; IMEC $\mathrm{L}_{\mathrm{L}}$ and $\mathrm{IMEC}_{\mathrm{B}}$ are the integration molar extinction coefficients, 2.22 and $1.67 \mathrm{~cm} \cdot \mu \mathrm{mol} / \mathrm{g}$ for Lewis and Brönsted acids, respectively; $r$ is the radius; and $w$ is the weight of the self-supporting catalyst disk.

$\mathrm{Ru}$ dispersion was measured by the $\mathrm{CO}$ chemisorption method with the Micromeritics ASAP 2020 system, $\mathrm{CO} / \mathrm{Ru}=1$ and a surface area of $8 \times 10^{-20} \mathrm{~m}^{2}$ per $\mathrm{Ru}$ atom were set as standard. The sample was initially pretreated at $200{ }^{\circ} \mathrm{C}$ under hydrogen and then purged with helium. Then, the catalyst was cooled to room temperature and CO pulses were injected through a calibrated on-line sampling valve. $\mathrm{CO}$ adsorption was assumed to be complete after three successive peaks showed the same peak areas. The number of Ru atoms at the external surface was calculated using the total quantity of CO adsorbed, obtained from the thermal conductivity detector (TCD) signal. The dispersion of $\mathrm{Ru}$ is equal to the number of $\mathrm{Ru}$ atoms at the external surface divided by the total number of Ru atoms.

\subsection{Reaction procedure and product analysis}

The reaction for the hydrodeoxygenation of lignin was performed in a $50 \mathrm{~mL}$ stainless-steel autoclave as follows: lignin (0.1 g), Ru/support catalyst or Ru@support catalyst (0.2 g), deionized water $(10 \mathrm{~mL})$, and cyclohexane $(5 \mathrm{~mL})$ were charged into the autoclave. Then, the reactor was sealed, purged three times with hydrogen, and charged to an initial pressure of $0.5 \mathrm{MPa}$ with $\mathrm{H}_{2}$. Finally, the reaction was carried out at $250{ }^{\circ} \mathrm{C}$, with magnetic stirring, for $20 \mathrm{~h}$.

The reactions for the hydrodeoxygenation of model compounds were also performed in a $50 \mathrm{~mL}$ stainless-steel autoclave. A typical experiment was carried out as follows: $p$-cresol (0.2 g), Ru@support (0.04 g) and deionized water (15 mL) were put into the autoclave. After being charged to an initial pressure of $0.5 \mathrm{MPa}$ with $\mathrm{H}_{2}$, the reaction was conducted at 250 ${ }^{\circ} \mathrm{C}$, under magnetic stirring, for $1 \mathrm{~h}$.

After the reaction, the reactor was quenched in an ice bath, and the organic products were extracted using ethyl acetate and qualitatively analyzed by gas chromatography-mass spectrometry (GC-MS) (Agilent 7890A-5975C) and quantitatively analyzed by a GC equipped with a flame ionization detector (GC-FID) (Agilent 7890B). Tridecane was added as an internal standard. After the first run, the catalysts were washed with a methanol and ethyl acetate solution, dried in a vacuum oven at $50{ }^{\circ} \mathrm{C}$ for $12 \mathrm{~h}$, then used for a second cycle. The mole yields of hydrocarbons were calculated based on the moles of lignin monomers in enzyme lignin, determined by the nitrobenzene oxidation method (NBO) (Table S1) [22].

Mole yield of $\mathrm{C}_{7}-\mathrm{C}_{9}$ hydrocarbons

moles of $\mathrm{C}_{7}-\mathrm{C}_{9}$ hydrocarbons produced $(\mu \mathrm{mol} /(\mathrm{g} \mathrm{LigB}))$

$=\overline{\text { moles of } \mathrm{C}_{7}-\mathrm{C}_{9} \text { hydrocarbons determined by NBO method }(\mu \mathrm{mol} /(\mathrm{g} \mathrm{LigB}))}$

\section{Results and discussion}

\subsection{Characterization of supports}

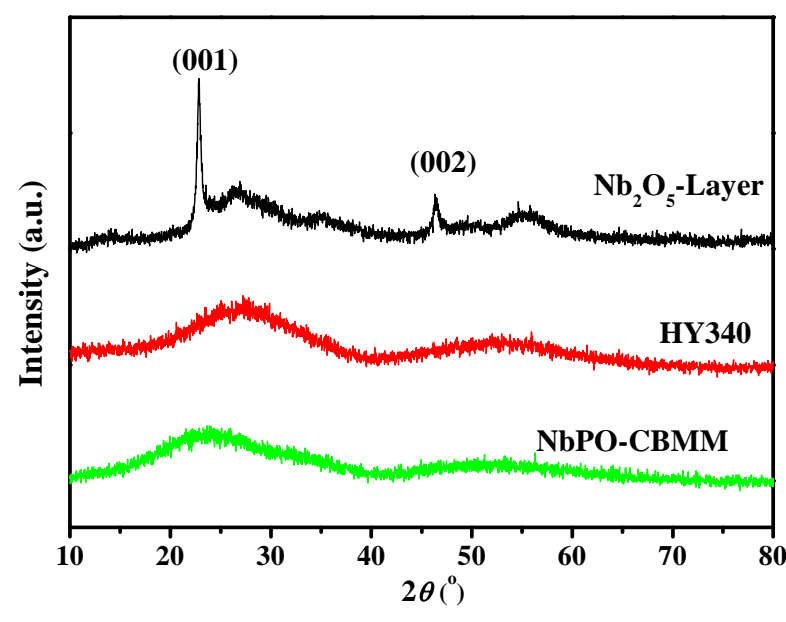

Fig. 1. The XRD patterns of the niobium-based materials.

\subsubsection{XRD}

XRD analysis was initially performed to confirm the phase-structure of the different supports (Fig. 1). The XRD patterns of both HY-340 and NbPO-CBMM show two broad peaks in the $2 \theta$ ranges of $15^{\circ}-40^{\circ}$ and $40^{\circ}-60^{\circ}$, indicating the amorphous nature of the samples. However, $\mathrm{Nb}_{2} \mathrm{O}_{5}$-Layer displays diffraction peaks at $2 \theta=22.7^{\circ}$ and $46.2^{\circ}$, attributed to the (001) and (002) diffraction planes, respectively [19]. This result hints at the probable layer-structure of our lab-made $\mathrm{Nb}_{2} \mathrm{O}_{5}$-Layer sample, which is verified by the high-resolution transmission electron microscope (HR-TEM) images (Fig. S1).

\subsubsection{BET}

The nitrogen adsorption-desorption isotherms of the $\mathrm{Nb}$-based materials are shown in Fig. 2. All the Nb-based materials exhibit Type IV isotherms with hysteresis loops, which are intermediate between the $\mathrm{H} 1$ and $\mathrm{H} 2$-types in the $P / P_{0}$ range from 0.4 to 0.8 , which is attributed to capillary condensation within the mesopores. The BET surface areas, pore diameters, and pore volumes of these materials are summarized in Table 1. The BET surface area and pore volume of $\mathrm{Nb}_{2} \mathrm{O}_{5}$-Layer are

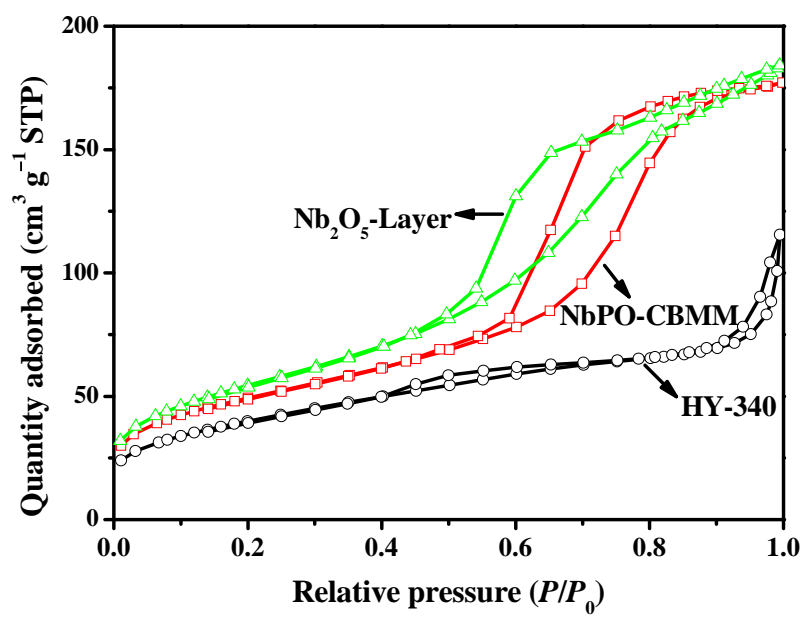

Fig. 2. $\mathrm{N}_{2}$ adsorption-desorption isotherms of $\mathrm{Nb}$-based materials. 
Table 1

Summary of physicochemical properties of the Nb-based materials.

\begin{tabular}{lccc}
\hline Sample & $\begin{array}{c}\text { BET surface area } \\
\left(\mathrm{m}^{2} / \mathrm{g}\right)\end{array}$ & $\begin{array}{c}\text { Pore size } \\
(\mathrm{nm})\end{array}$ & $\begin{array}{c}\text { Pore volume } \\
\left(\mathrm{cm}^{3} / \mathrm{g}\right)\end{array}$ \\
\hline $\mathrm{Nb}_{2} \mathrm{O}_{5}$-Layer & 197.1 & 4.6 & 0.29 \\
$\mathrm{HY}-340$ & 144.6 & 3.5 & 0.17 \\
$\mathrm{NbPO-CBMM}$ & 177.2 & 5.4 & 0.28 \\
\hline
\end{tabular}

$197.1 \mathrm{~m}^{2} / \mathrm{g}$ and $0.29 \mathrm{~cm}^{3} / \mathrm{g}$, respectively. Those of HY-340 and NbPO-CBMM are $144.6 \mathrm{~m}^{2} / \mathrm{g}$ and $0.17 \mathrm{~cm}^{3} / \mathrm{g}$, and $177.2 \mathrm{~m}^{2} / \mathrm{g}$ and $0.28 \mathrm{~cm}^{3} / \mathrm{g}$, respectively. It is evident that $\mathrm{Nb}_{2} \mathrm{O}_{5}$-Layer has a higher specific surface area and smaller pore size relative to those of the commercial Nb-based materials.

\subsection{3. $T G$}

Fig. 3 shows the results of thermogravimetric analysis for the Nb-based materials. The step observed on the TG curve at approximately $100{ }^{\circ} \mathrm{C}$, for all samples, is associated with dehydration. The observed weight loss in this step was $5.10 \%$ for $\mathrm{Nb}_{2} \mathrm{O}_{5}$-Layer, $6.88 \%$ for NbPO-CBMM, and $17.54 \%$ for $\mathrm{HY}-340$. For $\mathrm{Nb}_{2} \mathrm{O}_{5}$-Layer and NbPO-CBMM, it is caused by the desorption of physisorbed water. HY-340, a type of niobic acid, is rich in crystalline water and surface hydroxyl groups, so a higher weight loss occurred.

\subsubsection{Py-FTIR}

To investigate the different types of acidic sites on the support surfaces, the Py-FTIR spectra were recorded and the results are shown in Fig. 4, Table 2, and Table S2. In Fig. 4, the intense bands at 1445 and $1540 \mathrm{~cm}^{-1}$ are assigned to Lewis and Brönsted acid sites, respectively [21]. Moreover, the band at $1490 \mathrm{~cm}^{-1}$ is attributed to the adsorption of pyridine, due to a synergic effect of the co-existence of Brönsted and Lewis acid sites in the supports [23]. Brönsted and Lewis acid sites in the three $\mathrm{Nb}$-based samples were quantified using the Py-FTIR spectra (Table 2). The NbPO-CBMM sample possesses higher acidity $(921.8 \mu \mathrm{mol} / \mathrm{g})$ than the other samples; $629.0 \mu \mathrm{mol} / \mathrm{g}$ for HY-340, and $568.7 \mu \mathrm{mol} / \mathrm{g}$ for $\mathrm{Nb}_{2} \mathrm{O}_{5}$-Layer, respectively. In particular, as we expected, the commercial niobium materials possess more Brönsted acid sites (473.5 $\mu \mathrm{mol} / \mathrm{g}$ for

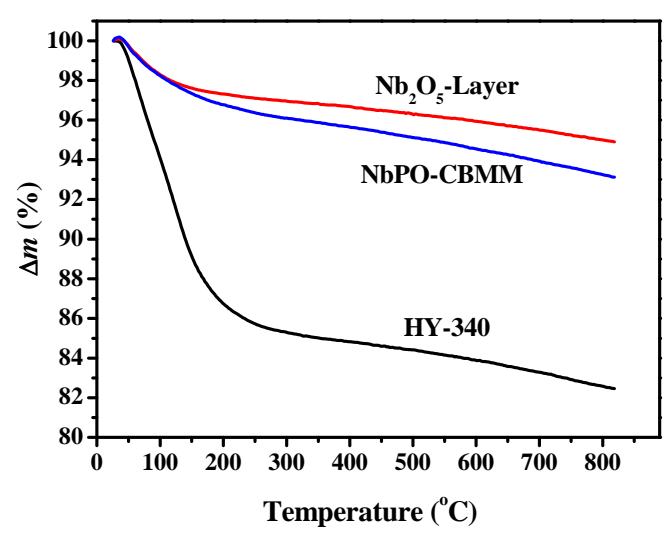

Fig. 3. TG profiles of the Nb-based materials.

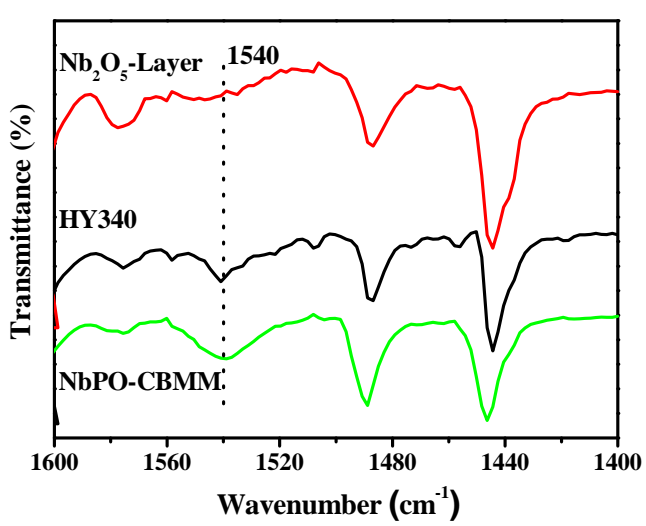

Fig. 4. Py-FTIR spectra of the Nb-based materials collected after treatment at $400{ }^{\circ} \mathrm{C}$, under vacuum.

NbPO-CBMM, and $147.5 \mu \mathrm{mol} / \mathrm{g}$ for $\mathrm{HY}-340$ ) than $\mathrm{Nb}_{2} \mathrm{O}_{5}$-Layer, which possesses merely $2.2 \mu \mathrm{mol} / \mathrm{g}$. Since the $\mathrm{Nb}_{2} \mathrm{O}_{5}$-Layer support contains a significantly larger number of Lewis acid sites, $\mathrm{Nb}_{2} \mathrm{O}_{5}$-Layer exhibits a lower Brönsted/Lewis acid ratio (0.004) than both HY-340 (0.3) and NbPO-CBMM (1.1).

\subsection{Catalytic conversion of lignin and p-cresol}

The catalytic activities were initially studied in the direct depolymerization and hydrodeoxygenation of lignin to hydrocarbons over the $\mathrm{Ru} / \mathrm{Nb}$-based catalysts and the results are summarized in Table 3. Four phenolic monomers were found after reactions over the Ru/HY-340 (15.6\%) and $\mathrm{Ru} / \mathrm{NbPO}-\mathrm{CBMM}$ (5.5\%) catalysts, while none of these oxygenated intermediates were detected during the catalytic test over $\mathrm{Ru} / \mathrm{Nb}_{2} \mathrm{O}_{5}$-Layer. It is well known that lignin is first depolymerized to phenolic monomers and that the resultant phenolic monomers are subsequently converted to arenes and cycloalkanes [24]. This is consistent with our results. Moreover, it can be seen from Table 3 that the mole yields of arenes and cycloalkanes resulting from the hydrodeoxygenation of phenolic monomers over $\mathrm{Ru} / \mathrm{Nb}_{2} \mathrm{O}_{5}$-Layer (91.1\%) are higher than those over Ru/HY-340 (67.5\%) and Ru/NbPO-CBMM (69.2\%). Thus, the catalytic performance results over the $\mathrm{Ru} / \mathrm{Nb}_{2} \mathrm{O}_{5}$-Layer catalyst highlight its excellent hydrodeoxygenation activity, which results in the rapid conversion of phenolic monomers into arenes and cycloalkanes, once the lignin has been depolymerized. Based on the Py-FTIR spectra, Lewis acid sites are the predominant component of the total acid sites on the surface of the $\mathrm{Nb}_{2} \mathrm{O}_{5}$-Layer support (only a few Brönsted acid sites were

Table 2

Quantities of Brönsted and Lewis acid sites on the Nb-based materials, quantified by Py-FTIR spectra, after evacuation at $400^{\circ} \mathrm{C}$.

\begin{tabular}{lcccc}
\hline $\begin{array}{l}\text { Nb-based } \\
\text { material }\end{array}$ & $\begin{array}{c}\text { Brönsted } \\
\text { acid } \\
(\mu \mathrm{mol} / \mathrm{g})\end{array}$ & $\begin{array}{c}\text { Lewis } \\
\text { acid } \\
(\mu \mathrm{mol} / \mathrm{g})\end{array}$ & $\begin{array}{c}\text { Total } \\
\text { acid } \\
(\mu \mathrm{mol} / \mathrm{g})\end{array}$ & $\begin{array}{c}\text { Ratio of } \\
\text { Brönsted acid } \\
/ \text { Lewis acid }\end{array}$ \\
\hline $\mathrm{Nb}_{2} \mathrm{O}_{5}$-Layer & 2.2 & 566.5 & 568.7 & 0.004 \\
$\mathrm{HY}-340$ & 147.5 & 481.5 & 629.0 & 0.3 \\
$\mathrm{NbPO-CBMM}$ & 473.5 & 448.3 & 921.8 & 1.1 \\
\hline
\end{tabular}


Table 3

The direct hydrodeoxygenation of lignin over the $\mathrm{Ru} / \mathrm{Nb}$-based catalysts.

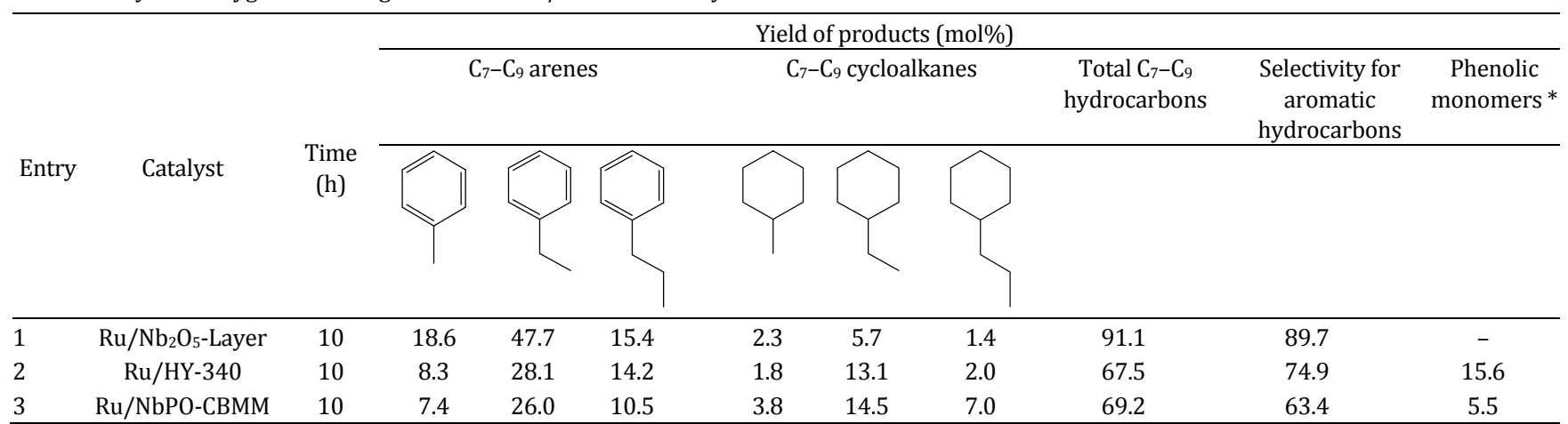

Reaction conditions: $0.1 \mathrm{~g}$ lignin, 0.2 g catalyst, $10 \mathrm{~mL} \mathrm{H}_{2} \mathrm{O}, 5 \mathrm{~mL}$ cyclohexane, $250{ }^{\circ} \mathrm{C}, 0.5 \mathrm{MPa} \mathrm{H}_{2}, 10 \mathrm{~h}$. The Ru loading is $5 \mathrm{wt} \%$.

* The mole yields of phenolic monomers are calculated based on the moles of lignin monomers in lignin; the phenolic monomers consist of the following:<smiles>CCCc1ccc(O)c(OC)c1</smiles>

observed). In addition, the quantity of Lewis acid sites over the three Nb-based supports is in the following sequence: $\mathrm{Nb}_{2} \mathrm{O}_{5}$-Layer $>\mathrm{HY}-340>$ NbPO-CBMM. The quantity of Lewis acid sites on the Nb-based supports shows a strong positive correlation with the depolymerization of lignin, i.e. the total mole yields of depolymerized products (including phenolic monomers). This result suggests that increasing the quantity of Lewis acid sites on the catalyst might be a promising strategy for the design of a better Nb-based lignin-conversion catalyst.

Moreover, the selectivity for $\mathrm{C}_{7}-\mathrm{C}_{9}$ aromatic hydrocarbons over the $\mathrm{Ru} / \mathrm{Nb}_{2} \mathrm{O}_{5}$-Layer catalyst was up to $89.7 \%$. Those over $\mathrm{Ru} / \mathrm{HY}-340$ and $\mathrm{Ru} / \mathrm{NbPO}-\mathrm{CBMM}$ were $74.9 \%$ and $63.4 \%$, respectively, with more cycloalkanes detected. This indicates that the hydrogenation of benzene rings is easier over both $\mathrm{Ru} / \mathrm{HY}-340$ and $\mathrm{Ru} / \mathrm{NbPO}-\mathrm{CBMM}$ catalysts than over the $\mathrm{Ru} / \mathrm{Nb}_{2} \mathrm{O}_{5}$-Layer catalyst. Generally speaking, $\mathrm{Ru}$ species are widely-accepted to act as the active sites in the hydrogenation processes [25-27], and the characteristics of the metal species (particle size or electronic state) over supports may also affect the reaction performance [28-31].

First, to determine the particle size of Ru over the niobium supports, measurements of $\mathrm{Ru}$ content and dispersion of $\mathrm{Ru}$ over the three Nb-based catalysts were carried out (Table 4). The $\mathrm{Ru}$ was best dispersed on the $\mathrm{Nb}_{2} \mathrm{O}_{5}$-Layer support (66.5\%), probably due to its higher specific surface area, while

Table 4

$\mathrm{Ru}$ contents and dispersions in the $\mathrm{Ru} / \mathrm{Nb}$-based catalysts.

\begin{tabular}{lccc}
\hline Catalyst & $\begin{array}{c}\text { Ru content } \\
\left.\text { ( }{ }^{\mathrm{a}} \%\right)\end{array}$ & $\begin{array}{c}\text { Dispersion }^{\mathrm{b}} \\
(\%)\end{array}$ & $\begin{array}{c}\text { Particle diameter }^{\mathrm{c}} \\
(\mathrm{nm})\end{array}$ \\
\hline $\mathrm{Ru} / \mathrm{Nb}_{2} \mathrm{O}_{5}$-Layer & 4.2 & 66.5 & 0.9 \\
$\mathrm{Ru} / \mathrm{HY}-340$ & 4.6 & 33.3 & 1.9 \\
$\mathrm{Ru} / \mathrm{NbPO}$-CBMM & 4.3 & 34.0 & 1.8 \\
\hline
\end{tabular}

a The metal loading was $5 \mathrm{wt} \%$ and the actual $\mathrm{Ru}$ contents of the catalysts were measured by ICP-AES analysis.

b The Ru dispersions were calculated using CO chemisorption.

c The Ru particle diameters were calculated using CO chemisorption. the Ru/HY-340 and Ru/NbPO-CBMM catalysts showed similar $\mathrm{Ru}$ dispersions (33.3\% and $34.0 \%$, respectively). In other words, the particles of $\mathrm{Ru}$ are smallest on the $\mathrm{Ru} / \mathrm{Nb}_{2} \mathrm{O}_{5}$-Layer catalyst. A small ruthenium particle is not favorable for the formation of cycloalkanes. According to our previous studies [18], arenes are generated by the direct cleavage of the Caromatic- $\mathrm{OH}$ bond in phenolic monomers, while cycloalkanes are formed by the removal of $-\mathrm{OH}$ after the hydrogenation of the benzene ring in phenolic monomers, which are competitive routes. Moreover, $\mathrm{Nb}$ species adsorb phenol via the oxygen atom of the $\mathrm{C}_{\text {aromatic }} \mathrm{O}$ bond, not via the benzene ring, thus further activating the $\mathrm{C}_{\text {aromatic }} \mathrm{O}$ bond. When the $\mathrm{Ru}$ particle size is too small to adsorb the benzene ring of the phenolic monomers, the $\mathrm{Nb}_{2} \mathrm{O}_{5}$ species first activates the $\mathrm{C}_{\text {aromatic }} \mathrm{O}$ bond, then arenes are generated. When the Ru particle size is large enough to adsorb the benzene ring of the phenolic monomers, the hydrogenation of the benzene ring of the phenolic monomers on Ru takes place and cycloalkanes are formed [27,32]. Thus, more aromatic hydrocarbons were obtained over the $\mathrm{Ru} / \mathrm{Nb}_{2} \mathrm{O}_{5}$-Layer catalyst due to the smaller $\mathrm{Ru}$ particles. The differences in selectivity for aromatics over the $\mathrm{Ru} / \mathrm{Nb}_{2} \mathrm{O}_{5}$-Layer, $\mathrm{Ru} / \mathrm{HY}-340$, and $\mathrm{Ru} / \mathrm{NbPO}-\mathrm{CBMM}$ catalysts demonstrate the size effect of Ru on hydrogenation.

The valence state of Ru in the different catalysts was studied using XPS analysis (Fig. 5). The binding energy at $280.2 \mathrm{eV}$ is characteristic of the $\mathrm{Ru}^{0}$ species (metallic $\mathrm{Ru}$ ). The shift in the $\mathrm{Ru} 3 d_{5 / 2}$ peak to a higher value $(281.2 \mathrm{eV})$ can be attributed to $\mathrm{Ru}^{4+}$ species, which most likely exist in the form of $\mathrm{RuO}_{2}$ [33,34]. Surprisingly, the surface $\mathrm{Ru}$ species over the $\mathrm{Ru} / \mathrm{Nb}_{2} \mathrm{O}_{5}$-Layer and $\mathrm{Ru} / \mathrm{HY}-340$ catalysts had a $3 d_{5 / 2}$ binding energy (BE) of $280.5 \mathrm{eV}$, which indicates that they are partially positively charged species $\left(\mathrm{Ru}^{\delta_{+}}\right)$. In the case of the $\mathrm{Ru} / \mathrm{NbPO}-\mathrm{CBMM}$ catalyst, the relevant Ru species is the metallic state $\left(280.2 \mathrm{eV}, \mathrm{Ru}^{0}\right)$. The differences in aromatic selectivities over the $\mathrm{Ru} / \mathrm{NbPO}-\mathrm{CBMM}$ and $\mathrm{Ru} / \mathrm{HY}-340$ catalysts, which 


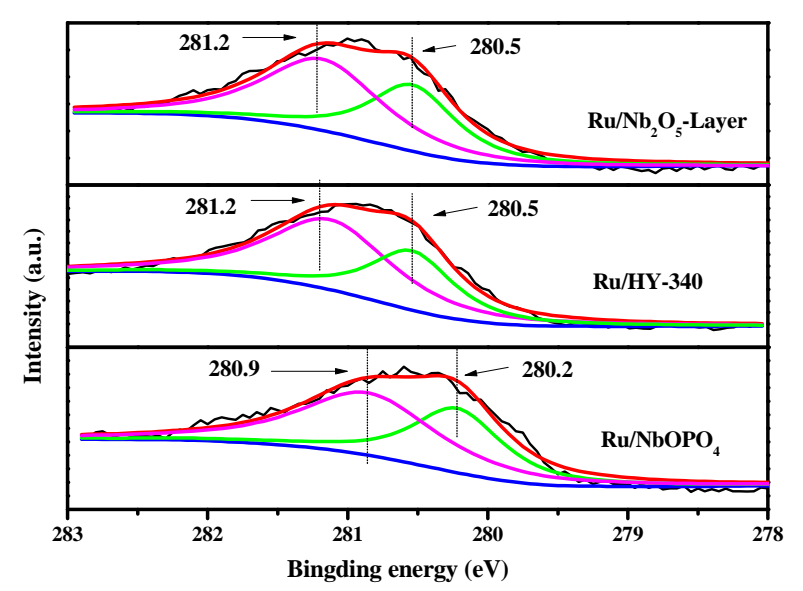

Fig. 5. $\mathrm{Ru} 3 d_{5 / 2}$ XPS spectra of the $\mathrm{Ru} / \mathrm{Nb}$-based catalysts.

have similar $\mathrm{Ru}$ dispersions, show the influence of electronic density on hydrogenation activity. The metallic Ru is beneficial for the hydrogenation of the benzene ring in phenolic monomers [35]. Hence, aromatic hydrocarbons were preferentially formed over $\mathrm{Ru} / \mathrm{Nb}_{2} \mathrm{O}_{5}$-Layer and $\mathrm{Ru} / \mathrm{HY}-340$, which contain more positively charged metallic Ru.

These results show that the ability of Ru to hydrodeoxygenate the depolymerized products of lignin is affected by both particle size and electronic density. This provides direction for the design of $\mathrm{Ru}$ catalysts for lignin conversion with high aromatic selectivities.

In order to investigate the roles of the Nb-based supports and $\mathrm{Ru}$ in the catalytic hydrodeoxygenation process, $p$-cresol was chosen as a candidate to exclude the complexity of lignin. Moreover, to rule out changes in $\mathrm{Ru}$ state caused by support, supported colloidal $\mathrm{Ru}$-catalysts on the three $\mathrm{Nb}$-based carriers were used to conduct the hydrodeoxygenation of $p$-cresol. The interaction between $\mathrm{Ru}$ and $\mathrm{Nb}$-based supports is relatively weak in catalysts synthesized by the colloid method and the Ru particle size is well-defined. Therefore, the actions of $\mathrm{Ru}$ and the Nb-based support can be distinguished. Moreover, the particle size of $\mathrm{Ru}$ on Nb-based catalysts synthesized by the impregnation method ranged from 0.9 to $1.9 \mathrm{~nm}$, according to the dispersion results (Table 4). Accordingly, Ru colloidal particles of 1.2 and $1.8 \mathrm{~nm}$ were investigated. The catalytic performances for the hydrodeoxygenation of $p$-cresol over the Ru@Nb-based catalysts are shown in Table 5. It was found that $p$-cresol conversions over the three catalysts were significantly different (56.8\% for Ru@ $\mathrm{Nb}_{2} \mathrm{O}_{5}$-Layer, 35.8\% for Ru@HY-340, and $25.1 \%$ for Ru@NbPO-CBMM), while the toluene selectivities were very similar (approximately 63.0\%) (Table 5, entries 1-3), when the Ru particle size was fixed at $1.2 \mathrm{~nm}$. This indicates that the conversion of $p$-cresol is most effective over the $\mathrm{Ru} / \mathrm{Nb}_{2} \mathrm{O}_{5}$-Layer catalyst and the properties of the Nb-based supports have the predominate influence on the conversion of $p$-cresol.

$\mathrm{Next}$, we used the $\mathrm{Nb}_{2} \mathrm{O}_{5}$-Layer as a support for colloidal $\mathrm{Ru}$ with a different particle size to study the effect of Ru particle size on the hydrodeoxygenation of $p$-cresol. As shown in Table 5 , the selectivity for toluene decreases from $62.0 \%$ to $53.9 \%$ with the increase in Ru particle size from 1.2 to $1.8 \mathrm{~nm}$ (Table 5, entries 1 and 4). This indicates that the size of Ru particles can affect the selectivity for toluene and that small Ru particles are advantageous for high toluene selectivity. Additionally, Nb-based supports with different Lewis acids affect the conversion of $p$-cresol, and the quantity of Lewis acid sites on the Nb-based supports showed a strong positive correlation with the conversion of $p$-cresol. These trends are also consistent with those in enzymatic lignin conversion reactions.

\subsection{Stability tests}

Since the stability of the catalyst is of significant importance from an industrial standpoint, the catalytic durability of the three catalysts was investigated. The results are shown in Table 6. The selectivity for aromatic hydrocarbons showed a slight change over the spent $\mathrm{Ru} / \mathrm{NbPO}-\mathrm{CBMM}$ catalyst, and the mole yield of $\mathrm{C}_{7}-\mathrm{C}_{9}$ hydrocarbons decreased, in comparison with the fresh catalyst. This is probably due to a slight decrease in specific surface area and a small loss of Ru (Table 7). A significant decrease in both the selectivity for aromatic hydrocarbons (from $74.2 \%$ to $61.4 \%$ ) and the yield of $\mathrm{C}_{7}-\mathrm{C}_{9}$ hydrocarbons (from $95.4 \%$ to $76.5 \%$ ) was observed over once-used $\mathrm{Ru} / \mathrm{HY}-340$ catalyst. Comparing the properties of the fresh and spent Ru/HY-340 catalysts, it is apparent that the structure of

Table 5

The hydrodeoxygenation of $p$-cresol over the Ru@Nb-based catalysts.
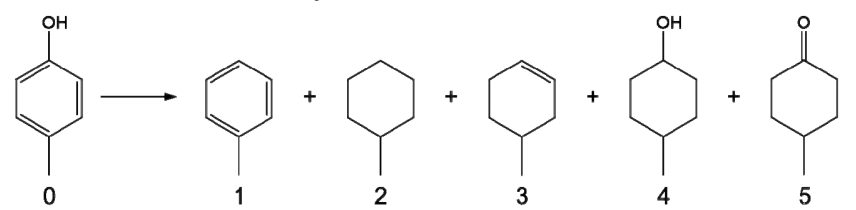

\begin{tabular}{|c|c|c|c|c|c|c|c|c|}
\hline \multirow{2}{*}{ Entry } & \multirow{2}{*}{ Catalyst } & \multirow{2}{*}{$\begin{array}{c}\text { Conv. } \\
(\%)\end{array}$} & \multicolumn{5}{|c|}{ Selectivity (\%) } & \multirow{2}{*}{ Carbon Balance (\%) } \\
\hline & & & 1 & 2 & 3 & 4 & 5 & \\
\hline 1 & $\mathrm{Ru} @ \mathrm{Nb}_{2} \mathrm{O}_{5}$-Layer ${ }^{\mathrm{a}}$ & 56.8 & 62.0 & 8.5 & 3.0 & 13.2 & 2.7 & 94.0 \\
\hline 2 & Ru@HY-340a & 35.8 & 62.7 & 9.7 & 2.7 & 9.6 & 2.5 & 95.4 \\
\hline 3 & Ru@NbPO-CBMMa & 25.1 & 62.8 & 6.3 & 5.1 & 10.9 & 2.1 & 96.7 \\
\hline 4 & $\mathrm{Ru} @ \mathrm{Nb}_{2} \mathrm{O}_{5}$-Layer b & 55.7 & 53.9 & 9.2 & 3.1 & 16.9 & 1.6 & 91.4 \\
\hline
\end{tabular}

a Reaction conditions: substrate $0.2 \mathrm{~g}$, catalyst $0.04 \mathrm{~g}, \mathrm{H}_{2} \mathrm{O} 15 \mathrm{ml}, 250{ }^{\circ} \mathrm{C}, \mathrm{H}_{2} 0.5 \mathrm{MPa}, 1 \mathrm{~h}$. The mean size of the Ru NPs is $1.2 \mathrm{~nm}$ (Fig. S4(a)).

b The mean size of the Ru NPs is $1.8 \mathrm{~nm}$ (Fig. S4(b)). 
Table 6

The direct hydrodeoxygenation of lignin over used catalysts.

\begin{tabular}{|c|c|c|c|c|c|c|c|c|c|c|}
\hline \multirow[t]{2}{*}{ Entry } & \multirow[t]{2}{*}{ Catalyst } & \multicolumn{8}{|c|}{ Yield of products (mol\%) } & \multirow[b]{2}{*}{ Others* } \\
\hline & & & 9 aren & & & cycloal & hes & $\begin{array}{c}\text { Total } \mathrm{C}_{7}-\mathrm{C}_{9} \\
\text { hydrocarbons }\end{array}$ & $\begin{array}{c}\text { Selectivity for } \\
\text { aromatic } \\
\text { hydrocarbons }\end{array}$ & \\
\hline 1 & $\mathrm{Ru} / \mathrm{Nb}_{2} \mathrm{O}_{5}$-Layer-1st use & 22.1 & 50.5 & 14.6 & 2.9 & 7.3 & 1.7 & 99.1 & 88.0 & 0.6 \\
\hline 2 & $\mathrm{Ru} / \mathrm{Nb}_{2} \mathrm{O}_{5}$-Layer-2nd use & 21.7 & 50.2 & 13.4 & 3.1 & 7.9 & 2.2 & 98.5 & 86.6 & 0.7 \\
\hline 3 & $\mathrm{Ru} / \mathrm{Nb}_{2} \mathrm{O}_{5}$-Layer-3rd use & 20.5 & 48.9 & 14.8 & 2.4 & 9.4 & 2.1 & 98.1 & 85.8 & 0.9 \\
\hline 4 & $\mathrm{Ru} / \mathrm{HY}-340$-spent & 7.4 & 29.0 & 10.6 & 3.9 & 20.3 & 5.3 & 76.5 & 61.4 & 0.5 \\
\hline 5 & $\mathrm{Ru} / \mathrm{NbPO}-\mathrm{CBMM}$-spent & 8.2 & 20.4 & 10.3 & 6.4 & 15.7 & 4.2 & 65.2 & 59.8 & 2.4 \\
\hline
\end{tabular}

Reaction conditions were: $0.1 \mathrm{~g}$ lignin, $0.2 \mathrm{~g}$ catalyst, $10 \mathrm{~mL} \mathrm{H} \mathrm{H}_{2}, 5 \mathrm{~mL}$ cyclohexane, $250{ }^{\circ} \mathrm{C}, \mathrm{H}_{2} 0.5 \mathrm{MPa}, 20 \mathrm{~h}$.

* The mass yields of $\mathrm{C}_{10}-\mathrm{C}_{15}$ hydrocarbons were calculated based on the mass of lignin.

The others consist of the following:

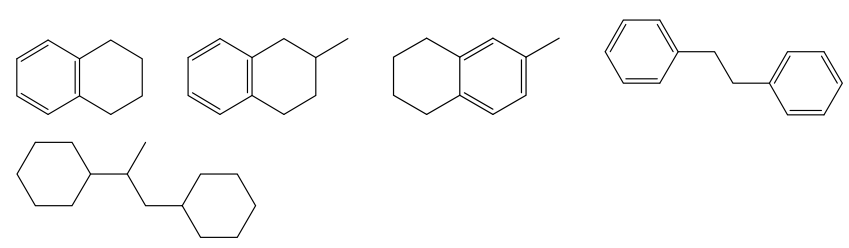

HY-340 transformed from an amorphous state to an orthorhombic crystalline structure, accompanied by a large decrease in specific surface area (Fig. S6(b)); furthermore, an obvious leach of Ru species was confirmed by ICP analysis (Table 7). These results indicate that the Ru/HY-340 catalyst has poor stability and does not effectively retain catalytic activity in this system. However, the $\mathrm{Ru} / \mathrm{Nb}_{2} \mathrm{O}_{5}$-Layer catalyst shows excellent recycling stability under the harsh reaction conditions, as the mole yield of $\mathrm{C}_{7}-\mathrm{C}_{9}$ hydrocarbons and selectivity for $\mathrm{C}_{7}-\mathrm{C}_{9}$ arenes remained at approximately $98 \%$ and $85 \%$, respectively, within the three runs (Table 6), despite slight $\mathrm{Ru}$ leaching (from 4.2 to $3.7 \mathrm{wt} \%$ ) and an insignificant decrease in the surface area (from 149.3 to $141.9 \mathrm{~m}^{2} / \mathrm{g}$ ) (Table 7). Our results clearly suggest that the $\mathrm{Ru} / \mathrm{Nb}_{2} \mathrm{O}_{5}$-Layer catalytic system is a promising candidate for the catalytic conversion of lignin to arenes.

\section{Conclusions}

In summary, we choose a variety of niobium materials, in-

Table 7

Characterization of fresh and used $\mathrm{Ru} / \mathrm{Nb}$-based catalysts.

\begin{tabular}{lcc}
\hline Catalyst & $A_{\text {BET }}\left(\mathrm{m}^{2} / \mathrm{g}\right)$ & $\begin{array}{c}\text { Metal element } \\
\text { analysis* }\end{array}$ \\
\hline $\mathrm{Ru} / \mathrm{Nb}_{2} \mathrm{O}_{5}$-Layer & 149.3 & 4.2 \\
$\mathrm{Ru} / \mathrm{Nb}_{2} \mathrm{O}_{5}$-Layer-3rd use & 141.9 & 3.7 \\
$\mathrm{Ru} / \mathrm{HY}^{-340}$ & 68.5 & 4.6 \\
$\mathrm{Ru} / \mathrm{HY}-340-1$ st use & 13.0 & 3.1 \\
$\mathrm{Ru} / \mathrm{NbPO}-\mathrm{CBMM}$ & 122.6 & 4.3 \\
$\mathrm{Ru} / \mathrm{NbPO-CBMM-1st} \mathrm{use}$ & 113.9 & 3.8 \\
\hline
\end{tabular}

* The metal loading was $5 \mathrm{wt} \%$ and the actual Ru contents of the Ru loaded catalysts were determined by the ICP method.
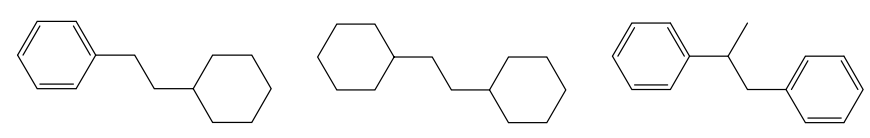

cluding commercial niobic acid (HY-340), niobium phosphate (NbPO-CBMM) and lab-made $\mathrm{Nb}_{2} \mathrm{O}_{5}\left(\mathrm{Nb}_{2} \mathrm{O}_{5}\right.$-Layer) as supports for $\mathrm{Ru}$ and investigated the influence of the properties of the support and $\mathrm{Ru}$ on the conversion of enzymatic lignin to aromatic hydrocarbons. It was found that the Lewis acid sites, rather than the Brönsted acid sites, of the support play an important role in the conversion of enzymatic lignin and $p$-cresol. The electronic density and size of the Ru particles have a considerable influence on the selectivity for aromatic hydrocarbons. In this study, the $\mathrm{Ru} / \mathrm{Nb}_{2} \mathrm{O}_{5}$-Layer catalyst was found to have a large quantity of Lewis acid sites, high specific surface area, and good dispersion of $\mathrm{Ru}$, which led to a mole yield of $99.1 \%$ for $\mathrm{C}_{7}-\mathrm{C}_{9}$ hydrocarbons and a selectivity of $88.1 \%$ for $\mathrm{C}_{7}-\mathrm{C}_{9}$ aromatic hydrocarbons in the reaction of enzymatic lignin to produce aromatic hydrocarbons. Moreover, the $\mathrm{Ru} / \mathrm{Nb}_{2} \mathrm{O}_{5}$-Layer catalyst showed good catalytic stability and retained a high catalytic performance even after three reaction cycles.

\section{Acknowledgments}

The research was sponsored financially by the National Natural Science Foundation of China (21832002, 21872050, 21808063) and the Natural Science Foundation of Shanghai (18ZR1408500).

\section{References}

[1] A. J. Ragauskas, C. K. Williams, B. H. Davison, G. Britovsek, J. Cairney, C. A. Eckert, Jr.W. J. Frederick, J. P. Hallett, D. J. Leak, C. L. Liotta, J. R. Mielenz, R. Murphy, R. Templer, T. Tschaplinski, Science, 2006, 311, 484-489. 


\section{Graphical Abstract}

Chin. J. Catal., 2019, 40: 609-617 doi: S1872-2067(19)63317-6

Depolymerization and hydrodeoxygenation of lignin to aromatic hydrocarbons with a Ru catalyst on a variety of Nb-based supports

Di Ma, Shenglu Lu, Xiaohui Liu *, Yong Guo, Yanqin Wang *

East China University of Science and Technology

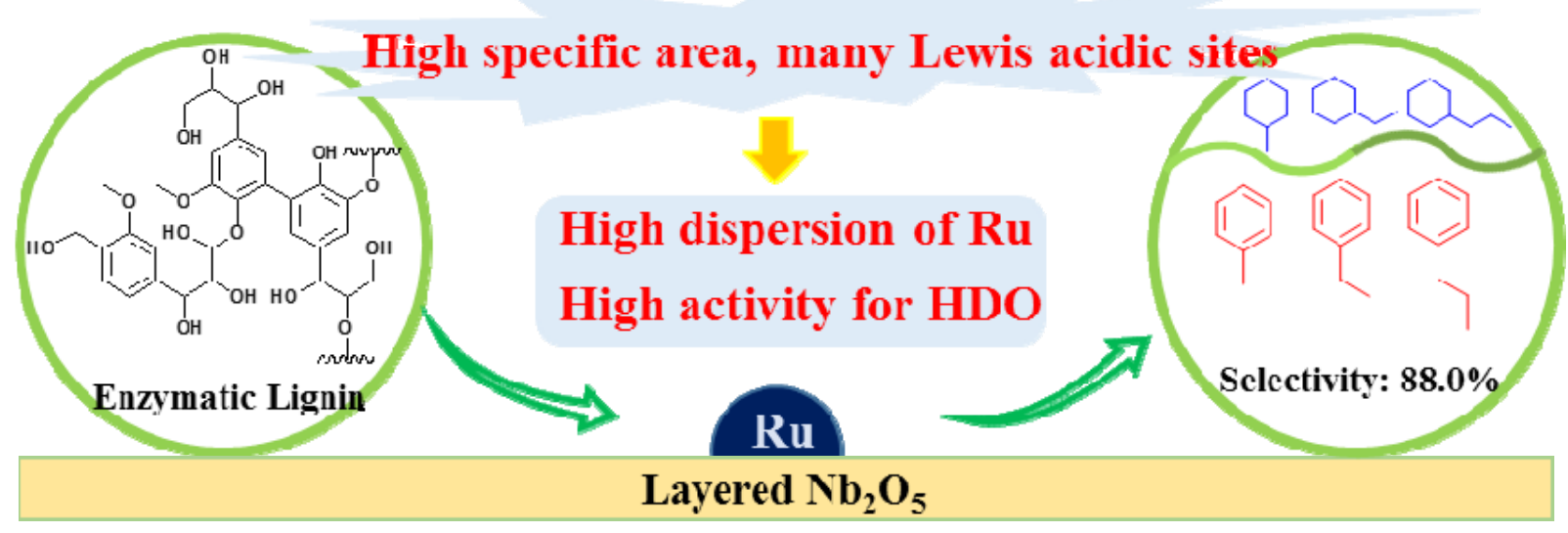

$\mathrm{Ru} / \mathrm{Nb}_{2} \mathrm{O}_{5}$-Layer is an efficient and stable catalyst for the conversion of lignin to arenes. Lewis acid sites on Nb carriers promote the lignin conversion and the electronic density and particle size of Ru affect the selectivity for arenes.

[2] J. N. Chheda, G. W. Huber, J. A. Dumesic, Angew. Chem. Int. Ed., 2007, 46, 7164-7183.

[3] P. Gallezot, Green Chem., 2007, 9, 295-302.

[4] P. Gallezot, Chem. Soc. Rev., 2012, 41, 1538-1558.

[5] X. C. Li, T. Y. Guo, Q. N. Xia, X. H. Liu, Y. Q. Wang, ACS Sustainable Chem. Eng., 2018, 6, 4390-4399.

[6] W. Zhang, J. Z. Chen, R. L. Liu, S. P. Wang, L. M. Chen, K. G. Li, ACS Sustainable Chem. Eng., 2014, 2, 683-691.

[7] H. Li, A. Riisager, S. Saravanamurugan, A. Pandey, R. S. Sangwan, S. Yang, R. Luque, ACS Catal., 2018, 8, 148-187.

[8] S. Gillet, M. Aguedo, L. Petitjean, A. R. C. Morais, A. M. da Costa Lopes, R. M. Łukasik, P. T. Anastas, Green Chem., 2017, 19, 4200-4233.

[9] C. Z. Li, X. C. Zhao, A. Q. Wang, G. W. Huber, T. Zhang, Chem. Rev., 2015, 115, 11559-11624.

[10] F. Chen, N. Li, W. T. Wang, A. Q. Wang, Y. Cong, X. D. Wang, T. Zhang, Chem. Commun., 2015, 51, 11876-11879.

[11] C. O. Tuck, E. Pérez, I. T. Horváth, R. A. Sheldon, M. Poliakoff, Science, 2012, 337, 695-699.

[12] J. Zakzeski, P. C. A. Bruijnincx, A. L. Jongerius, B. M. Weckhuysen, Chem. Rev., 2010, 110, 3552-3599.

[13] J. G. Zhang, L. Lombardo, G. Gözaydın, P. J. Dyson, N. Yan, Chin. J. Catal., 2018, 39, 1445-1452.

[14] X. Z. Wu, W. Q. Jiao, B. Z. Li, Y. M. Li, Y. H. Zhang, Q. R. Wang, Y. Tang, Chin. J. Catal., 2017, 38, 1216-1228.

[15] Q. N. Xia, Z. J. Chen, Y. Shao, X. Q. Gong, H. F. Wang, X. H. Liu, S. F. Parker, X. Han, S. H. Yang, Y. Q. Wang, Nat. Commun., 2016, 7, 11162.

[16] Q. N. Xia, C. Qian, X. H. Liu, X. Q. Gong, G. Z. Lu, Y. Q. Wang, Angew. Chem. Int. Ed., 2014, 53, 9755-9760.

[17] T. Y. Guo, Q. N. Xia, Y. Shao, X. H. Liu, Y. Q. Wang, Appl. Catal. A,
2017, 547, 30-36.

[18] Y. Shao, Q. N. Xia, L. Dong, X. H. Liu, X. Han, S. F. Parker, Y. Q. Cheng, L. L. Daemen, A. J. Ramirez-Cuesta, S. H. Yang, Y. Q. Wang, Nat. Commun., 2017, 8, 16104.

[19] T. Murayama, J. L. Chen, J. Hirata, K. Matsumoto, W. Ueda, Catal. Sci. Technol., 2017, 4, 4250-4257.

[20] P. Sun, X. D. Long, H. He, C. G. Xia, F. W. Li, ChemSusChem, 2013, 6, 2190-2197.

[21] C. A. Emeis, J. Catal., 1993, 141, 347-354.

[22] L. Shuai, M. T. Amiri, Y. M. Questell-Santiago, F. Héroguel, Y. D. Li, H. Kim, R. Meilan, C. Chapple, J. Ralph, J. S. Luterbacher, Science, 2016, 354, 329-333.

[23] F. M. T. Mendes, C. A. Perez, R. R. Soares, F. B. Noronha, M. Schmal, Catal. Today, 2003, 78, 449-458.

[24] V. Stavila, R. Parthasarathi, R. W. Davis, F. El Gabaly, K. L. Sale, B. A. Simmons, S. Singh, M. D. Allendorf, ACS Catal., 2016, 6, 55-59.

[25] M. V. Galkin, S. Sawadjoon, V. Rohde, M. Dawange, J. S. M. Samec, ChemCatChem, 2014, 6, 179-184.

[26] W. Y. Chen, J. Ji, X. Feng, X. Z. Duan, G. Qian, P. Li, X. G. Zhou, D. Chen, W. K. Yuan, J. Am. Chem. Soc., 2014, 136, 16736-16739.

[27] L. Dong, L. L. Yin, Q. N. Xia, X. H. Liu, X. Q. Gong, Y. Q. Wang, Catal. Sci. Technol., 2018, 8, 735-745.

[28] A. Q. Wang, T. Zhang, Acc. Chem. Res., 2012, 46, 1377-1386.

[29] M. V. Galkin, C. Dahlstrand, J. S. M. Samec, ChemSusChem, 2015, 8, 2187-2192.

[30] T. Tong, X. H. Liu; Y. Guo, M. N. Banis, Y. F. Hu, Y. Q. Wang, J. Catal., 2018, 365, 420-428.

[31] G. F. Liang, A. Q. Wang, N. Li, G. Xu, N. Yan, T. Zhang, Angew. Chem. Int. Ed., 2017, 56, 3050-3054.

[32] J. Dupont, J. D. Scholten, Chem. Soc. Rev., 2010, 39, 1780-1804.

[33] C. Elmasides, D. I. Kondarides, W. Grünert, X. E. Verykios, J. Phys. 
Chem. B, 1999, 103, 5227-5239.

[34] Z. W. Ma, S. L. Zhao, X. P. Pei, X. M. Xiong, B. Hu, Catal. Sci. Technol,, 2017, 7, 191-199.
[35] X. H. Liu, W. D. Jia, G. Y. Xu, Y. Zhang, Y. Fu, ACS Sustainable. Chem. Eng., 2017, 5, 8594-8601.

\section{木质素在不同 Ru/Nb基催化剂上解聚和脱氧加氢制芳烃化合物 \\ 马 迪 ${ }^{\dagger}$, 陆圣璐 ${ }^{\dagger}$, 刘晓晖 ${ }^{*}$, 郭 勇, 王艳芹 ${ }^{*}$ \\ 华东理工大学化学与分子工程学院, 工业催化研究所, 上海市功能材料化学重点实验室, 上海200237}

摘要: 木质素高效转化为芳烃是木质素利用的一个非常重要的过程, 一般通过解聚和脱氧加氢反应来实现. 我们曾发现 $\mathrm{NbOx}$ 物种在木质素及其模型化合物的 $\mathrm{C}-\mathrm{O}$ 键活化和断裂的过程中发挥了至关重要的作用. 本文分别选择两种商业的铌基 材料(HY-340和NbPO-CBMM)和实验室自制的具有层状结构的氧化铌材料 $\left(\mathrm{Nb}_{2} \mathrm{O}_{5}\right.$-Layer)为载体, 制备了负载型 $\mathrm{Ru}$ 催化剂, 将其用于木质素及其模型化合物的催化转化. 同时, 为了尽量避免 Ru与铌基载体相互作用的影响, 制备了较为均匀的Ru纳 米胶粒并吸附于铌基载体上, 得到 Ru@铌基催化剂, 并用于木质素模型化合物一对甲酚的催化转化反应中. 研究表明, 木 质素在所有的 $\mathrm{Ru} /$ 铌基催化剂上都可以得到比较高的 $\mathrm{C}_{7}-\mathrm{C}_{9}$ 碳氢化合物的收率. 其中, 在 $\mathrm{Ru}^{-} / \mathrm{Nb}_{2} \mathrm{O}_{5}-\mathrm{Layer}$ 催化剂上 $\mathrm{C}_{7}-\mathrm{C}_{9}$ 碳 氢化合物的摩尔收率为 $99.1 \%$, 选择性为 $88.0 \%$. 采用 X射线衍射、 $\mathrm{N}_{2}$ 吸附-脱附、热重分析、吡啶吸附红外光谱(Py-FTIR)、 $\mathrm{X}$ 射线光电子能谱(XPS) 以及CO化学吸附等技术表征了 $\mathrm{Ru} /$ 铌基催化剂的性能与铌基材料的性质、金属Ru颗粒大小及其表 面电子状态之间的关系.

Py-FTIR结果表明, $\mathrm{Nb}_{2} \mathrm{O}_{5}$-Layer材料上几乎没有Brönsted酸, 但含有最多的Lewis酸, 而NbPO-CBMM上的Lewis酸量最 低. 结合催化性能数据发现, 单体产物收率与铌基载体的Lewis量成正相关关系, 其中以 $\mathrm{Ru} / \mathrm{Nb}_{2} \mathrm{O}_{5}$-Layer催化剂上最高.

$\mathrm{CO}$ 化学吸附和XPS结果表明, 不同的铌基载体负载的金属Ru的分散度和电子状态都有差异. 在 $\mathrm{Ru}^{-} / \mathrm{Nb}_{2} \mathrm{O}_{5}-\mathrm{Layer}$ 上Ru 的分散度最好, 颗粒尺寸最小, 木质素转化得到的芳烃选择性最好; 在Ru/HY-340和Ru/NbPO-CBMM上, 虽然Ru的分散度 相近, 但其表面电子状态不同, Ru/HY-340上的金属态Ru带有更多的正电荷 $\delta+$, 其得到芳烃的选择性高于Ru/NbPO-CBMM. 由此可见, Ru的颗粒尺寸和表面电子状态会影响芳烃选择性.

对甲酚催化转化反应结果表明, Ru颗粒大小相同时, 铌基载体性质会影响对甲酚转化率; 而同一铌基载体上, Ru颗粒 大小则影响芳烃选择性, 较小的Ru颗粒有利于芳烃的生成.

关键词: 木质素; 芳烃化合物; 铌基载体; 路易斯酸; 钉

收稿日期: 2018-12-20. 接受日期: 2019-01-25. 出版日期: 2019-04-05.

*通讯联系人. 电子信箱: xhliu@ecust.edu.cn

\#通讯联系人. 电子信箱: wangyanqin@ecust.edu.cn

十共同第一作者.

基金来源：国家自然科学基金(21832002, 21872050, 21808063); 上海市自然科学基金(18ZR1408500).

本文的电子版全文由Elsevier出版社在ScienceDirect上出版(http://www.sciencedirect.com/science/journal/18722067). 